\title{
Unilateral clear hairy tongue sign
}

\section{Sinal da língua pilosa clara unilateral}

Péricles Maranhão-Filho', Hélio Ferreira Lopes²

A 53-year-old woman with history of paroxysms pain in the maxillary and mandibular right regions, with trigger zones on the nose wing and right tongue, and ipsilateral clear hairy tongue sign (Figure 1A). Following microvascular decompression surgery targeting a trigeminal nerve emergence vascular loop ${ }^{1}$, there was complete relief of pain and disappearance of the sign (Figure 1B). Hairy tongue discoloration is attributed to hypertrophy of keratinized filiform papillae that do not renew due to lack of mechanical stimulation in order to avoid pain ${ }^{2}$. We emphasize that pain elimination and return to normal tongue color are indicative signs of therapeutic success.

\section{Acknowledgment:}

The authors are grateful to Péricles Maranhão Neto for his technical assistance.
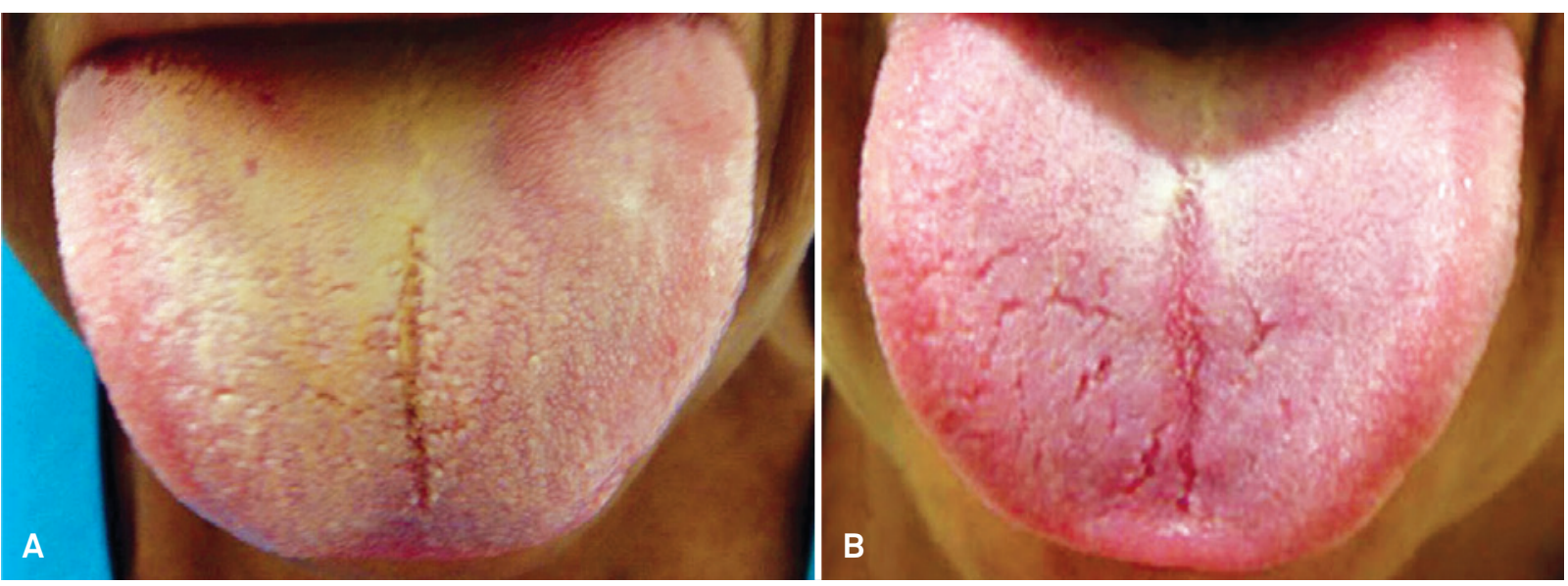

Figure. Right unilateral clear hairy tongue sign before surgery (A). Two months after surgery, normal tongue color due to re-epithelialization (B).

\section{References}

1. Maranhão-Filho PA. Neuralgia do trigêmeo com alça vascular bulbomedular (1996). In: Maranhão-Filho PA (Ed). Autores Brasileiros. Mais de um século de sinais, síndromes e outras contribuições neurológicas e neurocirúrgicas
(1878-1998). Editora Omnifarma, São Paulo, $1^{a}$ edição, 2008:83-85

2. Cheshire WP. Unilateral black hair tongue in trigeminal neuralgia. Headache 2004:44:908-910.

\footnotetext{
${ }^{1}$ Associate Professor of Neurology, Hospital Universitário Clementino Fraga, Universidade Federal do Rio de Janeiro/Neurologist, Instituto Nacional de Câncer, Hospital do Câncer I, Rio de Janeiro RJ, Brazil;

${ }^{2}$ Neurosurgeons. Head of the Departamento de Neurocirurgia, Instituto Nacional de Câncer, Hospital do Câncer I, Rio de Janeiro RJ, Brazil. Correspondence: Dr. Péricles Maranhão-Filho;Av Prefeito Dulcídio Cardoso 1680/1802; 22620-311 Rio de Janeiro RJ - Brasil; E-mail: pmaranhaofilho@gmail.com Conflict of interest: There is no conflict of interest to declare.
}

Received 03 June 2013; Accepted 11 June 2013. 